\title{
Uchodźcy w Europie. Uwarunkowania, istota, następstwa, red. Joanna Szymańska, Konstanty Adam Wojtaszczyk
}

\author{
Wydawnictwo Księgarnia Akademicka, Kraków 2017, 408 ss.
}

DOI: 10.19195/1643-0328.26.14

Kryzys migracyjny, jaki dotknął Europę w latach 2015-2017, był największy od zakończenia drugiej wojny światowej. Obnażył słabości globalnego reżimu ochrony uchodźców, wspólnego europejskiego systemu azylowego oraz polityk migracyjnych państw. Wzbudził wiele dyskusji, kontrowersji, obaw. Jednocześnie zmobilizował jednostki i społeczności do udzielania pomocy potrzebującym. Skutkiem kryzysu był wzrost zainteresowania problematyką uchodźstwa i migracji nie tylko wśród polityków, dziennikarzy, działaczy organizacji pozarządowych i opinii publicznej, lecz także wśród badaczy różnych dyscyplin nauki. Ów wzrost zainteresowania przejawia się między innymi w zwiększonej liczbie opracowań monograficznych i raportów z badań poświęconych tejże problematyce. Od wielu lat polscy badacze analizują kwestie związane z migracjami i uchodźstwem w bardzo różnym kontekście: przyczynowo-skutkowym, prawnym, proceduralnym, związanym $\mathrm{z}$ dyskryminacją, rasizmem, mową nienawiści, przemocą wobec cudzoziemców, warunków socjalno-bytowych panujących w ośrodkach dla uchodźców, zatrudnianiem cudzoziemców, ochroną ich zdrowia, dostępną pomocą prawną, integracją czy sytuacją na granicach. Mimo licznych publikacji opracowanie Uchodźcy w Europie. Uwarunkowania, istota, następstwa pod redakcją J. Szymańskiej i K.A. Wojtaszczyka zasługuje na szczególną uwagę. Jest ono niezwykle kompleksowe - podkreślmy — o czym świadczy spektrum omówionych zagadnień. We Wstępie redaktorzy wśród założonych celów publikacji wymienili przeanalizowanie:

- przyczyn, przebiegu oraz skutków napływu uchodźców do Europy,

- doświadczeń uchodźczych państw europejskich, ich polityk migracyjnych i azylowych,

- reakcji Unii Europejskiej jako całości oraz poszczególnych państw członkowskich na pojawiające się wyzwania migracyjne.

I cele te zostały w pełni osiągnięte.

Część pierwsza monografii została poświęcona różnym wymiarom zjawiska uchodźstwa: prawnemu, politycznemu, geograficznemu, społeczno-kulturowemu i psychologicznemu. Bardzo słusznie analiza rozpoczyna się od rozdziału poświęconego sytuacji prawnej uchodźców w kontekście praw człowieka. Autorka, co jest istotne dla klarowności przekazu dalszych części publikacji, wprowadza rozróżnienie form ochrony przysługujących cudzoziemcom. Rozważania te pozwalają czytelnikowi na zrozumienie zawiłości prawnych związanych z udzielaniem ochrony. Ponadto autorka przedstawia ewolucję regulacji prawnomiędzynarodowych odnoszących się do uchodźców. Jest to zwarte i syntetyczne opracowanie omawiające podstawowe dokumenty dotyczące sytuacji prawnej uchodźców z perspektywy międzynarodowych systemów ochrony praw człowieka (uniwersalnego, Rady Europy i Unii Europejskiej) oraz systemu prawa krajowego 
RP. W kolejnych dwóch rozdziałach możemy znaleźć rozważania dotyczące wymiaru politycznego uchodźstwa (z uwzględnieniem perspektywy historycznej, charakterystyki współczesnych trendów migracyjnych i wyzwań stojących przed państwami kreującymi i realizującymi polityki migracyjne) oraz wymiaru geograficznego, z bardzo rzetelną analizą dostępnych danych statystycznych. W rozdziale zaś dotyczącym wymiaru społeczno-kulturowego uchodźstwa znajduje się analiza wyników wybranych badan dotyczących postaw Polaków wobec imigrantów i uchodźców oraz wyzwań związanych z procesem integracji uchodźców w Polsce. Część pierwszą zamyka rozdział zatytułowany Wymiar psychologiczny uchodźstwa. Psychologiczne wyjaśnienia niechęci wobec uchodźców.

Część druga w całości jest analizą konsekwencji kryzysu uchodźczego dotykających Unię Europejską. Pierwsze dwa rozdziały (Kryzys uchodźczy w Europie - zarys problemu oraz Unia Europejska jako podmiot polityki wobec uchodźców) wprowadzają do problematyki. Zawierają omówienie danych statystycznych dotyczących napływu do państw Unii Europejskiej osób ubiegających się o ochronę, kierunków migracji, przyczyn kryzysu, jego przebiegu oraz tworzenia i ewolucji unijnego reżimu azylowego. Kolejne rozdziały natomiast ukazują następstwa kryzysu. Wśród zidentyfikowanych konsekwencji przeanalizowano między innymi wyzwania dotyczące funkcjonowania unijnej przestrzeni wolności, bezpieczeństwa i sprawiedliwości (w tym systemu Schengen, zagrożeń terrorystycznych, unijnego systemu azylowego, procesu integracji uchodźców) oraz przyszłości integracji europejskiej, z uwzględnieniem naruszenia zasady solidarności, wzrostu antyimigracyjnego radykalizmu i eurosceptycyzmu. Część kończy rozdział omawiający strategię Unii Europejskiej wobec kryzysu migracyjnego.

Kolejna - trzecia - część monografii poświęcona jest doświadczeniom i politykom państw członkowskich UE wobec uchodźców, z uwzględnieniem podziału geograficznego na kraje Europy Południowej, Zachodniej, Północnej, Środkowej i państwa bałtyckie. Rozważania otwiera rozdział, którego zasadniczym celem jest omówienie podstawowych różnic w zakresie doświadczeń wobec imigrantów i uchodźców między wspomnianymi geograficznymi obszarami Europy. W artykułach zamieszczonych w tej części czytelnik znajdzie analizę niezwykle ciekawych danych statystycznych dotyczących migracji i uchodźstwa, obowiązujących rozwiązań prawnych oraz reakcji poszczególnych rządów na kryzys migracyjny i rozwiązania proponowane przez Unię Europejską.

Ostatnia, czwarta, część dotyczy kryzysu uchodźczego z perspektywy Polski. Rozważania rozpoczyna artykuł zawierający historyczny przegląd postaw zagranicy wobec uchodźców z Polski i stosunku państwa polskiego do imigrantów politycznych, będący doskonałym wprowadzeniem, bez którego zrozumienie wielu zjawisk zachodzących obecnie w Polsce nie byłoby dla czytelnika łatwe. Kolejne części omawiają sytuację prawną cudzoziemców poszukujących schronienia na terytorium RP, stanowisko polskich rządów wobec unijnej strategii na rzecz przeciwdziałania kryzysowi migracyjnemu oraz wyzwania związane z przyjmowaniem uchodźców.

Struktura pracy wskazuje, że mamy do czynienia z pozycją monograficzną będącą niezwykle kompleksowym opracowaniem, uwzględniającym wieloaspektowość zjawiska uchodźstwa we współczesnym świecie. Należy podkreślić, że owa struktura jest bardzo starannie przemyślana, logiczna, konsekwentna i przejrzysta. Zjawisko uchodźstwa omawiane jest w znacznie szerszym kontekście migracji, często także z uwzględnieniem perspektywy historycznej. Poszerzenie spektrum badawczego i nieograniczenie go wyłącznie do uchodźstwa jest zabiegiem w pełni uzasadnionym, wręcz niezbędnym. Umożliwia bowiem czytelnikowi zrozumienie zjawiska migracji przymusowych, jego specyfiki, zakresu powiązań z innymi typami migracji. Struktura pracy wskazuje jednocześnie na uwzględnienie w badaniach trzech podstawowych dla zagadnienia 
wymiarów: globalnego, regionalnego (europejskiego) i krajowego. To kolejna ogromna zaleta recenzowanej publikacji.

Wśród atutów pracy, oprócz wspomnianej struktury, należy wymienić także:

- starannie dobrany zespół autorów reprezentujących różne obszary nauki (politologię, europeistykę, socjologię, psychologię, prawo, ekonomię, geografię) oraz różne ośrodki badawcze (w tym akademickie i think tanki),

- wykorzystanie różnych teorii, technik i metod badawczych,

- rzetelną analizę poszczególnych problemów opartą na dostępnej literaturze, aktach prawnych (międzynarodowych, unijnych i krajowych) i raportach,

- wykorzystanie w szerokim zakresie dostępnych danych statystycznych dotyczących migracji i uchodźstwa.

Wskazane elementy sprawiają, że praca jest wielodyscyplinarna, a analiza większości artykułów bardzo rzetelna i dobrze udokumentowana. W konsekwencji czytelnik znajdzie w publikacji odpowiedzi na wiele pytań oraz wątpliwości i kontrowersje, jakie pojawiły się w przestrzeni publicznej w związku z nasilonym w latach 2015-2017 napływem migrantów, w tym uchodźców, do państw Unii Europejskiej. Dodatkową zaletą pracy jest liczne grono potencjalnych odbiorców. Książka jest nie tylko doskonałą pomocą dydaktyczną dla studentów, ale - jak zauważają redaktorzy - czerpać z niej mogą badacze, urzędnicy, decydenci kreujący i realizujący polityki migracyjne oraz wszystkie osoby zainteresowane problematyką migracji i uchodźstwa. W tym kontekście elementem ułatwiającym lekturę jest zamieszczony słownik podstawowych pojęć i terminów.

Mimo wielu walorów omawianej publikacji recenzentka chciałaby wskazać kilka kwestii, które mogą budzić wątpliwości. Pierwsza dotyczy podziału treści. W książce możemy znaleźć powtórzenia, nie zawsze uzasadnione z merytorycznego punktu widzenia. Na przykład w części pierwszej, w artykule Wymiar normatywny uchodźstwa. Status uchodźcy z perspektywy praw człowieka autorka analizuje nie tylko formy ochrony przysługujące cudzoziemcom na podstawie aktów prawa międzynarodowego i unijnego (co jest zasadne), lecz także rozwiązania obowiązujące w prawie polskim. Należałoby się zastanowić, czy ten drugi element jest niezbędny, zważywszy, że regulacje prawne dotyczące udzielania ochrony cudzoziemcom na terytorium RP są omówione dość dokładnie w ostatniej części książki, w rozdziale Ochrona uchodźców w Polsce. Stosunek społeczeństwa polskiego do uchodźców omawiany jest w rozdziałach Wymiar społeczno-kulturowy uchodźstwa oraz Wymiar psychologiczny uchodźstwa. Psychologiczne wyjaśnienia niechęci wobec uchodźców. Wprawdzie autorzy omawiają wyniki badań dotyczących różnych aspektów zjawiska, ale być może czytelniejsze byłoby przedstawienie tych kwestii łącznie w rozdziale zamieszczonym w ostatniej części książki zajmującym się kryzysem uchodźczym z perspektywy Polski. Rozdział Wymiar społeczno-kulturowy uchodźstwa (zamieszczony w pierwszej części) mógłby wtedy dogłębniej analizować konsekwencje społeczne i kulturowe napływu uchodźców z metapoziomu, z uwzględnieniem perspektywy teoretycznej. Podobna uwaga dotyczy rozdziału Wymiar psychologiczny uchodźstwa. Psychologiczne wyjaśnienia niechęci wobec uchodźców. Recenzentka, być może niesłusznie, oczekiwała teoretycznej analizy czynników determinujących postawy wobec uchodźców oraz omówienia teorii psychologicznych przydatnych do wyjaśniania procesu kształtowania i zmiany postaw wobec uchodźców. Jednocześnie pragnie podkreślić, że wyniki badań omówione we wspomnianych rozdziałach są bardzo ciekawe, w zdecydowanej większości odnoszą się jednak do Polski, co zasadniczo zawęża obszar analizy i z tego względu powinny być zamieszczone w ostatniej części publikacji.

Druga uwaga dotyczy powielania w części artykułów danych liczbowych. Statystyki dotyczące skali uchodźstwa zostały rzetelnie omówione w rozdziale Wymiar geograficzny uchodźstwa, ana- 
lizowane są jednak także w innych częściach publikacji, na przykład Kryzys uchodźczy w Europie - zarys problemu, Integracja uchodźców z Afryki i Bliskiego Wschodu jako wyzwanie dla państw członkowskich Unii Europejskiej. Z jednej strony zabieg ten może być użyteczny przy założeniu, że część czytelników przeczyta tylko wyselekcjonowane artykuły i otrzyma niezbędne informacje, bez konieczności sięgania do innych części monografii. Z drugiej strony, dla czytelnika zainteresowanego całością analizowanie po raz kolejny tych samych danych statystycznych może być zbyteczne.

Trzecia uwaga odnosi się do powtarzających się w poszczególnych rozdziałach definicji pojęcia uchodźcy. Znaleźć je możemy przykładowo w artykułach Wymiar normatywny uchodźstwa. Status uchodźcy z perspektywy praw człowieka, Kryzys uchodźczy w Europie - zarys problemu, Integracja uchodźców z Afryki i Bliskiego Wschodu jako wyzwanie dla państw członkowskich Unii Europejskiej, Wielopłaszczyznowy wymiar problemu uchodźstwa w Unii Europejskiej. Zdaniem recenzentki, zważywszy na zamieszczenie słownika podstawowych pojęć i terminów, wielokrotne przytaczanie definicji z konwencji genewskiej o statusie uchodźców z 1951 roku jest zbędne.

Uwagi te absolutnie nie umniejszają wartości recenzowanej publikacji. Monografia Uchodźcy w Europie. Uwarunkowania, istota, następstwa jest opracowaniem kompleksowym, wieloaspektowym, rzetelnym i wnoszącym ogromny wkład w porządkowanie wiedzy na temat kryzysu migracyjnego. Z pewnością każdy czytelnik znajdzie w nim odpowiedzi na pytania dotyczące przyczyn, skali i konsekwencji przymusowych migracji. Publikacja ze wszech miar zasługuje na uwagę ze strony nie tylko akademików i studentów, lecz każdej osoby zainteresowanej problematyką migracji. 